\title{
Brucellosis Taking Over Covid: An Emerging New Pandemic
}

\author{
Dr. Mitra Ashok Shinde ${ }^{1 *}$, Dr. Prachi Hazari ${ }^{2}$, Dr. Shivani Hazari ${ }^{3}$, Dr. Sana Mohani ${ }^{4}$, Dr. Rahul VC Tiwari ${ }^{5}$, Dr. Heena \\ Tiwari $^{6}$ \\ ${ }^{1}$ 3rd year PG Student, Department of Prosthodontics, Crown and Bridge and Implantology, Daswani Dental College and Research Centre, Kota, \\ Rajasthan, India \\ ${ }^{2}$ Senior Lecturer, Department of Pediatric and Preventive Dentistry, Nanded Rural Dental College \& Research Centre, Nanded, Maharashtra, India \\ ${ }^{3}$ Post Graduate Student from Dept. Prosthodontics crown and bridges and implantology, Saraswati Dhanwantari Dental College and Hospital and Post \\ Graduate Research Institute, Parbhani, Maharashtra, India \\ ${ }^{4}$ Senior Lecturer, Department of Conservative Dentistry and Endodontics, Nanded Rural Dental College and Research Centre, Nanded, Maharashtra, \\ India \\ ${ }^{5}$ OMFS, FOGS, PhD Scholar, Department of OMFS, Narsinbhai Patel Dental College and Hospital, Sankalchand Patel University, Visnagar, Gujarat, \\ India \\ ${ }^{6}$ BDS, PGDHHM, Ex-Government Dental Surgeon, Kondagaon, Chhattisgarh, India
}

DOI: $\underline{10.36348 / \text { sjm.2020.v05i10.002 }}$ | Received: 17.09 .2020 | Accepted: 27.09 .2020 | Published: 07.10 .2020

*Corresponding Author: Dr. Mitra Ashok Shinde

\section{Abstract}

COVID-19 caused by SARS-CoV2, which emerged in the city of Wuhan in December 2019 has shook the entire world. Millions have been reportedly infected with the gruesome virus which has claimed numerous lives and has no cure yet. However, this has brought attention to the increasingly spreading zoonoses. Lately, news of an outbreak of Brucellosis has spread on news and social media, leaving a wave of apprehension among the people around the world. Since, there is no vaccine for brucellosis, there is a need to be spread information about it among the masses to aid in its prevention. This paper sheds light on the characteristics of brucellosis and its potential to spread across the world.

Keywords: Brucellosis, COVID, Pandemic.

Copyright @ 2020: This is an open-access article distributed under the terms of the Creative Commons Attribution license which permits unrestricted use, distribution, and reproduction in any medium for non-commercial use (NonCommercial, or CC-BY-NC) provided the original author and source are credited.

\section{INTRODUCTION}

The recent ongoing COVID-19 pandemic has brought awareness among not just researchers but also the common man about the increasing number of diseases that are spreading from animals to humans. The first case of COVID-19 was reported in the city of Wuhan, Hubei province, China in late December of 2019 [1]. On 30 ${ }^{\text {th }}$ January, 2019, the World Health organization reported a declared a public health emergency of international concern over the global outbreak of this disease [2] and on $7^{\text {th }}$ January 2020, they declared CoVID-19 a 'pandemic' [3].

\section{COVID}

The most common symptoms of COVID-19 are fever, dry cough, and tiredness. Other symptoms that are less common and may affect some patients include aches and pains, nasal congestion, headache, conjunctivitis, sore throat, diarrhea, loss of taste or smell or a rash on skin or discoloration of fingers or toes. These symptoms are usually mild and begin gradually. Some people become infected but only have very mild symptoms [4]. Genome sequencing of the virus was done and the virus was named a 2019-nCoV (novel coronavairus). It had a structure similar to other coronaviruses, i.e. a 'spike protein envelope [5], which resembled the sun's aura or a crown, hence the name 'coronavirus'. Due to its nucleotide sequence similarity with the coronavirus that causes Severe Acute Respiratory Syndrome (SARS) called SARS-CoV, it was later renamed as SARS-CoV2. On $11^{\text {th }}$ February, 2020, WHO named the disease caused by this virus as COVID-19 (Coronavirus Disease- 2019) [6] SARS$\mathrm{CoV} 2$ can be transmitted from person to person in two ways, viz. direct transmission and indirect/ contact transmission. Direct transmission refers to transmission of the virus from the infected to healthy person by coughing, sneezing or droplet inhalation. In the context of COVID-19, airborne transmission may be possible in specific circumstances and settings in which procedures or support treatments that generate aerosols are performed; i.e., endotracheal intubation, bronchoscopy, open suctioning, administration of nebulized treatment, manual ventilation before intubation, turning the patient to the prone position, disconnecting the patient from the ventilator, non-invasive positive-pressure ventilation, tracheostomy, and cardiopulmonary resuscitation [7]. Indirect/ contact transmission is the spread of the virus from infected surfaces to oral, nasal or eye 
mucous membranes [2, 8-10]. Guidelines to combat COVID-19 have been formulated by governments across the world to aid in prevention and to halt the spread of the dreaded disease. According to the WHO, COVID-19 can be prevented by washing hands regularly with soap and water or an alcohol-based hand rub, by maintaining a distance of at least 1 meter (3 feet) between people, wearing a mask in public, practicing respiratory hygiene and avoiding touching eyes, nose and mouth. Health authorities should be contacted if symptoms appear and people with minor symptoms are advised to self-isolate [11].

\section{CROSS SPECIES TRANSMISSION}

Since the early cases of the virus emerged from a seafood market of China, it is believed to be 'spilled over' from animals to humans. This has brought awareness among not just researchers but also the common man about the increasing number of diseases that are spreading from animals to humans. A few examples include SARS, Avian influenza A (H7N9), Ebola and many others. Recently, cases of spread of Brucellosis in China have been reported which is causing a wave of terror among the people. As per reports, thousands of people in Southwest China have tested to be positive for Brucellosis [12].

\section{BRUCELLOSIS}

Brucellosis is a bacterial disease caused by the Brucella species of bacteria. It affects cattle, sheep, goats, pigs and some other animals. The infection remains in the animal throughout its life. It can be transmitted to humans by direct contact with the infected animal or by drinking an infected animal's unpasteurized milk or consuming such milk products. It is also called "undulant" fever since it causes episodes of high fever, especially in the evening. Human-tohuman transmission of brucellosis is rare. The clinical features of the disease include gradual onset of persistent fever, chills, sweating, headache, muscle pain, backache, joint pain, fatigue, weakness and weight loss. Human brucellosis can cause chronic debilitating illness. Complications may affect any of the organ systems. Incubation period of the disease may extend from one week to several months [13]. One of the common features of brucellosis in animals is abortion and in recent years it has been found that it can also cause obstetric complications in human pregnancies as well [14]. Brucellosis is not a new disease and is endemic in many countries in Asia including China, India, Indonesia and Thailand, and also in South America, the Mediterranean and the Middle East [13]. According to the World Health Organization (WHO) factsheet, although approximately 500000 brucellosis cases are reported annually, the true incidence is always much higher than the reported number of cases [15]. Eventhough, it is not a new disease, its incidence is high, especially in parts of Asia and there is no vaccine has been developed for the disease yet. It can be prevented by Consume only pasteurized or boiled milk and dairy products from cows, sheep, and goats, by thoroughly cooking meat before consumption and exercising care in handling and disposal of placenta, discharges and fetuses from cattle. Infection-control should be practiced extensively in areas endemic to the disease [13].

\section{CONCLUSION}

The COVID-19 pandemic has brought a great deal of much needed attention to zoonotic diseases. Although, human-to-human spread of brucellosis is rare, its incidence isn't. Since, there is no vaccine for brucellosis, there is a need to be spread information about it among the masses to aid in its prevention.

\section{REFERENCES}

1. Zhu, N., Zhang, D., Wang, W., Li, X., Yang, B., Song, J., ... \& Niu, P. (2020). China Novel Coronavirus Investigating and Research Team. A novel coronavirus from patients with pneumonia in China, 2019. N Engl J Med, 382(8), 727-733.

2. Peng, X., Xu, X., Li, Y., Cheng, L., Zhou, X., \& Ren, B. (2020). Transmission routes of 2019$\mathrm{nCoV}$ and controls in dental practice. International Journal of Oral Science, 12(1), 1-6.

3. World Health Organization. Coronavirus disease 2019 (COVID-19): situation report, 72.

4. https://www.who.int/emergencies/diseases/novelcoronavirus-2019/question-and-answers-hub/q-adetail/q-a-coronaviruses\#: :text=symptoms.

5. Li, F. (2016). Structure, function, and evolution of coronavirus spike proteins. Annual review of virology, 3, 237-261.

6. Cascella, M., Rajnik, M., Cuomo, A., Dulebohn, S. C., \& Di Napoli, R. (2020). Features, evaluation and treatment coronavirus (COVID-19). In Statpearls [internet]. StatPearls Publishing.

7. https://www.who.int/newsroom/commentaries/detail/modes-of-transmissionof-virus-causing-covid-19-implications-for-ipcprecaution-recommendations.

8. Lu, C. W., Liu, X. F., \& Jia, Z. F. (2020). 2019$\mathrm{nCoV}$ transmission through the ocular surface must not be ignored. Lancet (London, England), 395(10224), e39.

9. Liu, J., Liao, X., Qian, S., Yuan, J., Wang, F., Liu, Y., ... \& Zhang, Z. (2020). Community transmission of severe acute respiratory syndrome coronavirus 2, Shenzhen, China, 2020.

10. Chan, J. F. W., Yuan, S., Kok, K. H., To, K. K. W., Chu, H., Yang, J., ... \& Tsoi, H. W. (2020). A familial cluster of pneumonia associated with the 2019 novel coronavirus indicating person-toperson transmission: a study of a family cluster. The Lancet, 395(10223), 514-523.

11. https://www.who.int/emergencies/diseases/novelcoronavirus-2019/advice-for-public.

12. https://edition.cnn.com/2020/09/17/asia/chinabrucellosis-outbreak-intl-hnk/index.html. 
13. World Health Organization. A brief guide to emerging infectious diseases and zoonoses.

14. Inan, A., Erdem, H., Elaldi, N., Gulsun, S., Karahocagil, M. K., Pekok, A. U., ... \& HaykirSolay, A. (2019). Brucellosis in pregnancy: results of multicenter ID-IRI study. European Journal of
Clinical Microbiology \& Infectious Diseases, 38(7), 1261-1268.

15. Jiang, H., O’Callaghan, D., \& Ding, J. B. (2020). Brucellosis in China: history, progress and challenge. Infectious Diseases of Poverty, 9(1), 14. 